\title{
Poverty Reduction in South Sumatera with Optimization of Village Funds, Allocation of Village Funds, and Village Original Income
}

\author{
Rita Martini ${ }^{1 *}$, Endah Widyastuti ${ }^{1}$, Sukmini Hartati ${ }^{1}$, Zulkifli Zulkifli ${ }^{1}$, \\ Mardhiah Mardhiah ${ }^{1}$ \\ ${ }^{1}$ Accounting Department, Polytechnic State of Sriwijaya, Palembang 30139, Indonesia
${ }^{*}$ Corresponding author. Email: ritamartini@ polsri.ac.id
}

\begin{abstract}
In the province of South Sumatra, this study intends to examine the impact of village funds, village fund allocations, and village original income. For 2015-2019, 14 districts/cities in South Sumatra province were used as examples. Purposive sampling is the sampling technique used to determine the sample. The findings show that the village fund has a partly negative impact on poverty, whereas the allocation of village funds and village original income has a partial positive and considerable impact on poverty. Furthermore, the village fund, village fund allocation, and village original income all have a significant and favorable impact on poverty. Due to a lack of data, the research time in this study was cut short. It is suggested that more research be done to expand the quantity of data samples, prolong the study time, and include more independent factors. In South Sumatra province, district/city administrations are expected to be able to maximize the utilization of village funds in order to fulfill the goal of poverty alleviation through local expenditures.
\end{abstract}

Keywords: village financial governance, poverty.

\section{INTRODUCTION}

Poverty is the inability to meet the minimum standard of living in accordance with the level of eligibility for living. As an aggregate measure, the poverty rate in a region is used to measure the level of welfare in that region. Some of the factors that cause poverty these include low local and global economic growth, low levels of education and mastery of technology, limited natural resources, high population growth, and unfavorable political stability. Poverty in South Sumatra increased by 12.98 percent in 2020, according to data given by the Central Statistics Agency of the Republic of Indonesia (BPS). Meanwhile, 12.56 percent of the population was impoverished in 2019. South Sumatra is now the $10^{\text {th }}$ poorest province in Indonesia, and the third poorest province in Sumatra, due to the increase in the number of impoverished people.

From the above phenomenon, a breakthrough is needed in reducing poverty in the village. Economic growth in China is supported by fiscal reforms accompanied by rural reforms [1]. This research is also in accordance with [2], that fiscal decentralization has actually provided a catch-up impact for previously lagging regions. Thus, it can be concluded that rural development is a prerequisite for increasing economic growth that carries the concept of equity [3]. Therefore, the implementation of village development will require adequate financing or sources of village revenue [4] and [5].

BPS explained that the percentage of poverty in urban areas reached 1.26 percent while the percentage of poverty in villages was 13.47 percent, this shows that the poverty rate is still high in rural areas. With the rise in poverty, the government has established a number of programs to address the issue, including the village fund program and the distribution of village monies. The greater the size of village funds and village fund allocations, the lower the poverty rate is predicted to be [5]. Increasing the welfare of the community is one strategy to promote village development. The bigger the income of the village fund, the better it is believed that the welfare of rural communities will be realized and rural poverty will be reduced.

Poverty is significantly influenced by village funds and village fund allocations [5]. Village finances and village fund distributions have no substantial effect on poverty, according to study. The income from village funds has a substantial impact on poverty. Village fund revenue has a considerable impact on poverty [6] and [7]. The population included in this study differs from earlier studies in that it includes all districts/cities in South Sumatra. There is also an additional variable, which is the village's original income. 


\section{LITERATURE REVIEW RESEARCH HYPOTHESES}

Village funds are a source of village funds originating from the state budget and expenditure that are transferred through the district/city regional income and expenditure budget and are used to administer government, village development, coaching, and community empowerment, according to Minister of Home Affairs Regulation No. 113 of 2014. The allocation of village funds [8] is $10 \%$ of the balancing funds received by the regency/city in the APBD after deducting the special allocation funds.

According to the Central Statistics Agency, village fund income is revenue from various village government efforts to collect funds for village needs in financing routine/development activities. Poverty is a state of being unable to achieve one's basic necessities, such as health, reasonable living standards, freedom, self-respect, and a sense of respect for others, as well as the nation's and state's grim future [2] [3].

Research hypothesis:

H1 : Village fund significant impact on poverty.

$\mathrm{H} 2$ : Allocation village fund is influential significant impact on poverty.

H3 : Village original income has a significant effect on poverty.

H4 : Village funds, village fund allocations, and village original income have a significant or simultaneous effect on poverty.

\section{RESEARCH METHODOLOGY}

This is a causal associative research that uses quantitative approaches. Quantitative data in the form of numbers or numbers that are processed or evaluated using mathematical computation procedures is the sort of data employed [9]. Secondary data sources were utilised in this investigation. The LRA APBDes collected straight from the DPMD and BPS make up this secondary data.

The population in this study were all regencies in South Sumatra Province which consisted of 17 regencies/cities. The sampling technique used to determine the sample in this study is purposive sampling or taking sample members from the population with certain considerations. The sampling criteria are presented in Table 1.
Table 1: Research Sample Determination Criteria

\begin{tabular}{|l|l|c|}
\hline No & \multicolumn{1}{|c|}{ Criteria } & Amount \\
\hline 1 & $\begin{array}{l}\text { Regencies/cities in South Sumatra } \\
\text { Province }\end{array}$ & 17 \\
\hline 2 & $\begin{array}{l}\text { Regencies/cities that do not } \\
\text { receive village fund and village } \\
\text { fund allocation }\end{array}$ & $(3)$ \\
\hline 3 & $\begin{array}{l}\text { LRA APBDes which has village } \\
\text { fund and village fund allocation } \\
\text { components. }\end{array}$ & 14 \\
\hline 4 & Research year & 60 \\
\hline & Total Units of Analysis & 5 \\
\hline
\end{tabular}

Source: Data processed (2021)

Based on the sampling calculation above, the number of districts in South Sumatra Province that can be sampled is 14 regency/city.

There are 3 (three) independent variables and one dependent variable, which are as follows:

Independent Variable: $\mathrm{Y}=$ Poverty

Dependent Variable:

$\mathrm{X} 1=$ Village Fund

$\mathrm{X} 2=$ Village Fund Allocation

$\mathrm{X} 3=$ Village Original Income

According to descriptive statistics, the average value (mean), standard deviation, variance, maximum, minimum, total, range, kurtosis, and skewness provide an overview or description of data (distribution). The average (mean), standard deviation, maximum, and minimum values of the research data are displayed in this study.

Multiple linear analytic models were used to test hypotheses and estimate the strength of the independent variable's influence on the dependent variable. The Coefficient of Determination Test ( $\mathrm{R}^{2}$ Test) is used to determine how well the independent variable can partially or simultaneously explain the variance of the dependent variable.

The F test is used to see if all of the model's independent or independent variables have a joint effect on the dependent variable. If the likelihood of significance is greater than $0.05, \mathrm{H}_{0}$ is accepted as the basis for decision making for the $\mathrm{F}$ test. $\mathrm{H}_{0}$ is rejected if the likelihood of significance is less than $0.05 . \mathrm{H}_{0}$ is rejected and $\mathrm{H}_{1}$ is approved if the calculated $\mathrm{F}_{\text {value }}$ is greater than the $\mathrm{F}_{\text {table. }}$. The $\mathrm{t}$-statistical test essentially reveals how much one explanatory/independent variable explains the variation of the dependent variable on its own. 
If the statistic $t_{\text {count }}$ equals statistic $t_{\text {table }}$ in this test, $\mathrm{H}_{0}$ is approved and $\mathrm{H}_{1}$ is rejected. $\mathrm{H}_{0}$ is rejected and $\mathrm{H}_{1}$ is approved if $t_{\text {count }}>t_{\text {table. }} H_{0}$ is accepted if the significance probability is greater than 0.05 , and $\mathrm{H}_{0}$ is rejected if the significance probability is less than 0.05 , based on the probability numbers.

\section{RESULT AND DISCUSSION}

\subsection{Result}

In South Sumatra Province, Table 2 displays the findings of descriptive statistics on variable data on village funds, allocation of village funds, village original income, and the number of poor people.

Table 2: Descriptive Statistics Results Descriptive Statistics

\begin{tabular}{|l|r|r|r|r|r|}
\hline & \multicolumn{1}{|c|}{ N } & \multicolumn{1}{|c|}{ Minimum } & \multicolumn{1}{c|}{ Maximum } & \multicolumn{1}{c|}{ mean } & \multicolumn{1}{c|}{ Std. Deviation } \\
\hline Village Fund & 70 & 1670439 & 301179650 & 140087235,49 & 82893023,218 \\
\hline Allocation of village funds & 69 & 2080200 & 247212551 & 66346379.91 & 53241163,347 \\
\hline Village Original Income & 58 & 3270 & 15698380 & 2854576.71 & 3687729,811 \\
\hline Poverty & 70 & 2047 & 13407 & 6172.81 & 3131,783 \\
\hline Valid N (list wise) & 58 & & & & \\
\hline
\end{tabular}

Source: SPSS Output, 2021

\subsubsection{Classic Assumption Test}

The purpose of the normality test is to see if the regression model, dependent variable, and independent variable all have a normal distribution. Because the data had a significant value of 0.200 , which was more than 0.05 , it could be said that the data had a normal distribution.

The goal of this multicollinearity test is to see if the regression model established a relationship between independent and dependent variables. It is found that all independent variables have a tolerance value greater than 10 and a VIF less than 10, indicating that there are no multicollinearity issues in this study.

The autocorrelation test was used to see if there was a link between the confounding error in period $t$ and the confounding error in period $\mathrm{t}-1$ in the linear regression model. The DW value was 1.868 based on the Durbin Watson test results. The DW value is in the range of
$\mathrm{dU}=1.7028$ and 4-dU=2.2972 (see Durbin Watson table). As a result, there is no evidence of an autocorrelation problem.

The heteroscedasticity test determines whether there is an inequality of variance between the residuals of one observation and the residuals of another observation in the regression model. The dots do not create a discernible pattern, as evidenced by the results of the heteroscedasticity test. On the Y axis, the points are spaced above and below the number 0 . As a result, the regression model does not have a problem with heteroscedasticity.

\subsubsection{Multiple Linear Regression Analysis}

Multiple linear analytic models were used to test hypotheses and estimate the strength of the independent variable's influence on the dependent variable. The findings of the multiple linear regression analysis are shown in Table 3.

Table 3: Results of Multiple Linear Regression Analysis

Coefficients $^{\mathrm{a}}$

\begin{tabular}{|c|c|c|c|c|c|c|}
\hline \multirow{2}{*}{\multicolumn{2}{|c|}{ Model }} & \multicolumn{2}{|c|}{ Unstandardized Coefficients } & \multirow{2}{*}{$\begin{array}{c}\text { Standardized Coefficients } \\
\text { Beta }\end{array}$} & \multirow[b]{2}{*}{$\mathrm{t}$} & \multirow[b]{2}{*}{ Sig. } \\
\hline & & B & Std. Error & & & \\
\hline \multirow[t]{4}{*}{1} & (Constant) & 2703,224 & 588,015 & & 4,597 & ,000 \\
\hline & Village Fund & 0.000004 & ,000 & ,113 & 1,157 & ,252 \\
\hline & Allocation of village funds & 0.000028 & ,000 & ,491 & 5.062 &, 000 \\
\hline & Village Original Income &, 000457 & ,000 & ,557 & 6,730 & ,000 \\
\hline
\end{tabular}

a. Dependent Variable: Poverty

Source: SPSS Output, 2021 
The regression equation is as follows, based on the output of multiple linear regression analysis:

$$
\begin{aligned}
& \mathrm{Y}=2703.224+0.000004 \mathrm{X} 1+0.000028 \mathrm{X} 2+ \\
& 0.000457 \mathrm{X} 3+\mathrm{e}
\end{aligned}
$$

From the regression model above, it can be identified that the village fund, village fund allocation, and village original income have a positive relationship towards poverty. The regression is then deduced as follows:

1. The constant value of 2703.224 indicates that the average poverty level in the regency/city will rise by 2703.224, assuming that the village fund, village fund allocation, and village original revenue remain unchanged.

2. The village fund variable has a coefficient value of 0.000004 , which means that if the village fund variable increases by $1 \%$ and the other variables remain constant, the poverty variable will increase by 0.000004 .

3. The coefficient value of 0.000028 for the village fund allocation variable suggests that if the village fund allocation variable grows by one percent while the other factors remain constant, the poverty variable will increase by 0.000028 .

4. The coefficient value of 0.000457 for the village original income variable suggests that if the village original income variable grows by one percent while the other factors remain constant, the poverty variable will increase by 0.000457 .

\subsubsection{Hypothesis Testing}

$\mathrm{T}_{\text {count }}<\mathrm{t}_{\text {table }}(1.157<1.996)$ and sig value $>0.05$ $(0.252>0.05)$ are the values of the village fund variable. As a result, it can be stated that the village fund has a limited impact on poverty. $t_{\text {count }}>t_{\text {table }}$ $(5,062>1,996)$ and sig $0.05(0.000<0.05)$ are the values of the Village Fund Allocation variable. As a result, it may be argued that the distribution of village funds has a limited impact on poverty. $\mathrm{T}_{\text {count }}>\mathrm{t}_{\text {table }}$ $(6.730>1,996)$ and sig $0.05(0.0000 .05)$ are the values of village initial income. As a result, it can be inferred that village original income has a limited impact on poverty.

The computed F of the F statistical test is 31.975 , as seen in the results of the F statistical test. The $F_{\text {table }}$ of 2.74 yielded the following results. $\mathrm{H}_{1}$ is acceptable because $\mathrm{F}_{\text {count }}>\mathrm{F}_{\text {table }}(31.975>2.74) . \mathrm{H}_{4}$ is accepted based on the significant value in the $\mathrm{F}$ test being less than 0.05 , which is 0.000 , and the estimated $F_{\text {value }}$ being $31.975>2.74\left(\mathrm{~F}_{\text {table }}\right)$. As a result, the village fund, village fund allocation, and village original income all have an impact on poverty.
The coefficient of determination test (Adjusted $\mathrm{R}$ Square), often known as the coefficient of determination, yielded a result of 0.620 . This indicates that the variable $X$ has a 62 percent contributing influence on the variable $\mathrm{Y}$. Other independent variables not included in this study account for the remainder $(100$ percent -62 percent $=38$ percent $)$.

\subsection{Discussion}

\subsubsection{The Effect of Village Funds on Poverty}

The $t_{\text {count }}$ for the village fund is 1.157 , according to hypothesis testing results. When the $t_{\text {count }}$ obtained is compared to the $t_{\text {table }}$ value of 1.996 , the $t_{\text {count }}$ obtained is less than the $t_{\text {table }}$ value. Furthermore, the significance value of the village fund allocation variable is 0.252 , which is above the $5 \%$ significant level $(=0.05)$. It can be concluded that the village fund variable has no influence or has no association with poverty. This signifies that the study's first hypothesis has been disproved.

The community fund has no effect on poverty levels, according to this study. According to the purpose of providing village fund transfers, namely to improve the welfare of rural communities and the quality of life of rural communities as well as to reduce village poverty, the village fund should be able to make a significant contribution to the poverty level in the district/city. This signifies that the district/city governments in South Sumatra Province have yet to achieve the village fund's aims in practice. This study agrees with [10], who claim that the village fund has little impact on poverty levels. In contrast to the findings of [7], the village fund had a positive impact on poverty in 11 districts of South Sumatra. According to the findings of [11], the village fund has an impact on district/city poverty. Because of the utilization of samples and different time periods, this is the case.

\subsubsection{The Effect of Village Fund Allocations on Poverty}

The $t_{\text {count }}$ for the village fund allocation is 5.062, as determined via hypothesis testing. The $t_{\text {count }}$ obtained is more than the $t_{\text {table }}$ value of 1,996 when compared to the $\mathrm{t}_{\text {table }}$ value. Furthermore, the village fund variable has a significance value of 0.00 , which is less than the $5 \%$ significant level $(=0.05)$. As a result, it can be inferred that the village fund allocation variable has a positive and substantial relationship or influence on poverty in South Sumatra Province districts/cities from 2015 to 2019. This suggests that the study's second hypothesis is correct. 
The findings of this study are consistent with the goals of the transfer of the village fund allocation, which are to reduce poverty and inequality while also boosting community welfare. This signifies that the district/city authority in South Sumatra Province has met the village fund allocation targets in practice. As a result, it can be stated that there is a link between village fund allocation and poverty, and that increasing village fund allocation will effect the level of poverty in the regency/city of South Sumatra.

This study agrees with [6], who claim that village money distribution has a considerable positive effect on poverty, implying that the better the village fund allocation is, the more it affects poverty levels. [11], for example, claim that village money allocation has an impact on district/city poverty. In contrast to the findings of [10], the allocation of village funds had no effect on poverty levels.

\subsubsection{The Effect of Village Original Income on Poverty}

The original income count for the village is 6.730 . The $t_{\text {count }}$ obtained is more than the $t_{\text {table }}$ value of 1,996 when compared to the $t_{\text {table }}$ value. Furthermore, the significance value of the village original income variable is 0.00 , which is less than the $5 \%$ significant level $(=0.05)$. As a result, it's possible to conclude that the village original income variable has a positive and considerable impact on poverty. This suggests that the study's third hypothesis is correct.

The findings of this study are consistent with the goals of village original income, which is to use it as a source of funding for village development and management, one of which is to alleviate poverty. As a result, it can be stated that there is a link between village original income and poverty, and that if village original income rises, the poverty level of the regency/city in South Sumatra Province will rise as well. This study supports [7], who found that village original income had a substantial positive effect on poverty, implying that the higher the village original income, the lower the poverty level.

\subsubsection{The Effect of Village Funds, Village Fund Allocations, and Village Original Income on Poverty}

The $F_{\text {count }}$ value of the influence of the village fund, village fund allocation, and village original revenue on poverty is 31,975 . When compared to the $F_{\text {table }}$ value of $2.74, F_{\text {count }}$ is lower, implying that the variables of village fund, village fund allocation, and village original income together have a positive and significant relationship or influence on poverty in regencies/cities in South Sumatra Province. This suggests that the study's fourth hypothesis is correct.
A significance level of 0.000 was also found in this investigation, which is lower than a significance level of 0.05 . This demonstrates that poverty is influenced by the village fund, village fund allocation, and village original revenue. Furthermore, the coefficient of determination of Adjusted $\mathrm{R}^{2}$ is 0.62 , based on the findings of an examination of the strength of the link between the dependent variable and the independent variable or an analysis to determine how much the independent variable explains the dependent variable.

This study reveals that the allocation of village funds and village original income has a significant impact on poverty levels, indicating that the allocation of village funds and village original income is sufficient to alleviate poverty in districts/cities in South Sumatra. Meanwhile, in South Sumatra Province, regency/city village fund transfers must be used to maximize the attainment of the village fund's objectives so that it can lower poverty levels. The village fund and village fund allocation variables have an effect on district/city poverty, according to [11] [12]. Unlike [10], who claim that the village fund and its allocation have no impact on poverty,

\section{CONCLUSION}

The village fund has a partly negative impact on poverty, however the allocation of village funds and village original income has a partial positive and considerable impact. In districts/city administrations in South Sumatra province, village fund, village fund allocation, and village original income all have a favorable and significant effect on poverty in 20152019. The distribution of village money and village original revenue have a significant impact on poverty levels. This situation demonstrates that the distribution of community money and original revenue is adequate to alleviate poverty. Furthermore, in order to reduce poverty levels in the province of South Sumatra, district/city village fund transfers must be used to maximize the attainment of village fund objectives.

\section{ACKNOWLEDGMENT}

Thankfully acknowledges scientific dialogue with our Indonesian counterparts from the State Polytechnic of Sriwijaya. The authors would like to thank the anonymous reviewers who provided feedback on this presentation at the $5^{\text {th }}$ FIRST 2021 International Conference. Thank you also to the reviewers who provided feedback during the current review process.

\section{REFERENCES}

[1] Ratna, S. D., \& Irama, O. N. (2018.) Pengaruh Alokasi Dana Desa terhadap Kemiskinan: Studi Kasus di Provinsi Sumatera Utara. Jurnal Akuntansi dan Bisnis, 4 (2) November 2018. 
[2] Martowardojo, Agus D.W. (2012). Satu Dasawarsa Implementasi Otonomi Daerah: dalam Perspektif Desentralisasi Fiskal. Kongres ISEI Ke-XVIII.

[3] Martini, R., Sari, K. R., Somadi, T., \& Karman, I. W. (2019). Financial Independence of the South Sumatra Regional Government" Proceedings of the International Conference on Applied Science and Technology 2019-Social Sciences Track (iCASTSS 2019). 354, pp. 360-364. Denpasar: Atlantis Press. https://doi.org/10.2991/icastss19.2019 .75

[4] Martini, R., Agustin, R., \& Sari, K. R. 2020. Accrual Discretion Policy on Excess/Less Budget Financing at the Provincial Level. TEST Engineering \& Management, 82, 9925-9935.

[5] Martini, R., Widyastuti, E., Hartati, S., Zulkifli, Mayasari, R., \& Mardhiah. (2021). Poverty in South Sumatra Province is Viewed from Village Fund and Village Fund Allocation. Atlantis Highlights in Social Sciences, Education and Humanities. Volume 1. pp. 100-107.

[6] Dewi, R. S., \& Irama, O. N. (2018). Pengaruh Pendapatan Desa, dan Alokasi Dana Desa terhadap Belanja Desa dan Kemiskinan. Jurnal Riset Akuntansi Multiparadigma (JRAM).

[7] Kawulur, S., Koleangan, R. A., \& Wauran, P. C. (2019). Analisa Pengaruh Pendapatan Asli Desa dan Dana Desa Dalam Menurunkan Tingkat Kemiskinan di 11 Kabupaten Provinsi Sulawesi Utara. Jurnal Berkala Ilmiah Efisiensi .

[8] Undang-Undang No. 6 Tahun 2014 tentang Desa

[9] Sugiyono. (2014). Metode Penelitian Pendidikan Pendekatan Kuantitatif, Kualitatif, dan R\&D. Bandung: Alfabeta.

[10] Lalira, D., Nakoko, A. T., \& Rorong, I. P. (2018). Pengaruh Dana Desa Dan Alokasi Dana Desa terhadap Tingkat Kemiskinan di Kecamatan Gemeh Kabupaten Kepulauan Talaud. Jurnal Berkala Ilmiah Efisiensi.

[11] Susilowati, N. I., Susilowati, D., \& Hadi, S. (2017). Pengaruh Alokasi Dana Desa, Dana Desa, Belanja Modal, dan Produk Domestik Regional Bruto Terhadap Kemiskinan Kabupaten/Kota Di Jawa Timur. Jurnal Ilmu Ekonomi. 